\title{
Transport expansion threatens the Arctic
}

The expansion of transport infrastructure endangers many wild places, particularly in the tropics ("Roads to riches or ruin", W. F. Laurance et al., Perspective, 27 October, p. 442). Opening transport routes through the Arctic is also likely to damage fragile ecosystems and potentially exacerbate global climate change.

Aided by unparalleled ice retreat (1), Russia, the United States, Germany, and Scandinavian countries have accelerated navigation and exploration of the Arctic (2). In the summer of 2017, China completed its first navigation of the Northwest Passage (3). Through its New Silk-Road Initiatives that include cooperation with Russia for the "Silk-Road on ice" (4), the country has seized the opportunity to increase its involvement in Arctic affairs. Nearly half of China's gross domestic product is shipping dependent, and the lure of shorter routes has driven growing interest in Arctic shipping.

Shipping can, however, exacerbate environmental pollution. In Scandinavia, ship emissions increase deposition of nitrate by 30 to $50 \%$ and sulphate by 10 to $25 \%$ (5), endangering human health and increasing ocean acidification. Deposition of black carbon aerosols can reduce albedo, accelerating snowmelt and ice loss (6). With limited infrastructure and poor weather, accidental spills of oil and chemicals are major concerns. For example, the 1989 Exxon Valdez oil spill has had lasting impacts in the Arctic due to difficulties of cleaning up in icy waters (7). Concerns have increased after recent tragic spills (8). Foreign species can also be introduced through ballast or wastewater discharges (9). Shipping through areas of critical ecological concern such as whale foraging zones or migration corridors may threaten wildlife, for example, the North Atlantic right whale (10).

With limited implementation of the Paris Agreement, particularly from the United States, Arctic shipping could be easier in the future. Nevertheless, the International Maritime Organization's Polar Code includes waste management, improving infrastructure, and routing agreements (11). Strict enforcement of such international codes and national laws will be necessary to minimize environmental impacts on Arctic environments (12).

\section{Hong Yang, ${ }^{1,2 *}$ Mingguo Ma, ${ }^{1}$ Julian R. Thompson, ${ }^{3}$ Roger J. Flower ${ }^{3}$}

${ }^{1}$ Chongqing Engineering Research Center for Remote Sensing Big Data Application, Chongqing Key Laboratory of Karst Environment, School of Geographical Sciences, Southwest University, Chongqing, 400715, China. ${ }^{2}$ Department of Geography and Environmental Science, University of Reading, Reading, RG6 6AB, UK. ${ }^{3}$ UCL Department of Geography, University College London, London, WC1E 6BT, UK.

*Corresponding author. Email: hongyanghy@gmail.com

\section{REFERENCES}

1.Y. Aksenov et al., Mar. Policy 75, 300 (2017).

2.Y. R. Zhang, Q. Meng, L. Y. Zhang, Mar. Pol. 73, 53 (2016).

3.Central Government of P. R. of China, "China successfully finished the first navigation of the Northwest Passage in Arctic" (2017); www.gov.cn/xinwen/201709/07/content_5223349.htm [in Chinese].

4. Xinhua, "Interview: "Silk Road on Ice" to enhance Russia-China cooperation in Arctic: Russian expert" (2017); http://news.xinhuanet.com/english/201711/27/c_136782902.htm

5.S. B. Dalsøren, Ø. Endresen, I. S. Isaksen, G. Gravir, E. Sørgård, J. Geophys. Res. Atmos. 112, D02310(2007).

6. J. Browse, K. Carslaw, A. Schmidt, J. Corbett, Geophys. Res. Lett. 40, 4459 (2013).

7.World Wildlife Fund, "20 years on, Arctic unprepared for another Exxon Valdez" (2009); http://wwf.panda.org/?159442/20-years-on-Arctic-unprepared-for-another-ExxonValdez.

8.A. Jernelov, Nature 466, 182 (2010).

9.L. Jing, B. Chen, B. Zhang, H. Peng. Environ Rev20, 83 (2012).

10. N. Hong, Res. Transport. Econ. 35, 50 (2012).

11.International Maritime Organization, "Guidelines for ships operating in polar waters" (2010); www.imo.org/en/Publications/Documents/Attachments/Pages\%20from\%20E190E.pdf.

12. H. Yang, X. Huang, J. R. Thompson, R. J. Flower. Science 347, 834 (2015). 